\title{
Personal Remittance, A Reagent of Macroeconomic Stability in the Perspective of Pakistan (2005-2017)
}

\author{
Mahpara Naeem \\ PhD Scholar, Department of Commerce, University of Karachi \\ Dr.Sadaf Mustafa \\ Department of Commerce, University of Karachi \\ Imran ul Haque \\ MPhil Scholar, Department of Commerce, University of Karachi
}

\begin{abstract}
Pakistan is a semi-industrialized economy, which mainly comprehends fabrics, chemicals, food dispensation, cultivation and other activities. Economy of Pakistan is at very stirring phase in structural and financial point of view such as unfavorable balance of payments and high debt profile. To disrupt these unfavorable economic balances many peripheral economic factors act as a source of income or core factor of advantageous balances such as FDI, Remittances, Exports, Foreign aids etc. So this study is aimed to detect pros and cons of personal remittances along with correlation with macroeconomic volatilities. Data is collected from secondary sources during time span of 2005-2017. The period is chosen for study is 2002 to 2017 and numerical data is used for validity. Data is evaluated through statistical software EVIEWS. Standardized criteria is assumed to accept or reject the hypothesis. On the basis of inferences, policies and implication are given in the shape of recommendation for curative measures.
\end{abstract}

Keywords: Personal Remittances, Current account balance, Unemployment, Inflation

DOI: $10.7176 / \mathrm{JESD} / 10-6-10$

Publication date:March $31^{\text {st }} 2019$

\section{Introduction}

1.1. Background of Study:

Being an emergent country, Pakistan is an imperative and dominant economy of south Asian continent. Economy of Pakistan is at very challenging face in structural and financial point of view such as unfavorable balance of payments and high debt profile. To disrupt these unfavorable economic balances many external economic factors act as a source of income or core factor of favorable balances such as FDI, Remittances, Exports, Foreign aids etc. Remittances as a source of inflow for an economy by the passages of time the term remittances is manipulated and known as "Personal Remittances".

Alessandra Alfieri and Ivo Havinga," DEFINITION OF REMITTANCES (2006)" ${ }^{1}$ defines personal remittances as follows:

Personal remittances $=$ compensation of employees - social contributions + Personal transfers + capital transfers between households

Personal remittance a broader definition of Remittances and a new term introduced in Balance of payments' part, comprises of all current transfers between citizens or non-citizen and habitants or inhabitants neglecting sender's earning resources and bonding between households. In developing countries personal remittances are gradually increasing due to unemployment rates, improper job responsibilities and other household expenditures. In Pakistan during 2005-2017'there is an increasing trend of personal remittances due to financial crisis of economy and individuals as well showing in the given graph.

\footnotetext{
${ }^{1}$ UNITED NATIONS DEPARTMENT OF ECONOMIC AND SOCIAL AFFAIRS STATISTICS DIVISION
} 


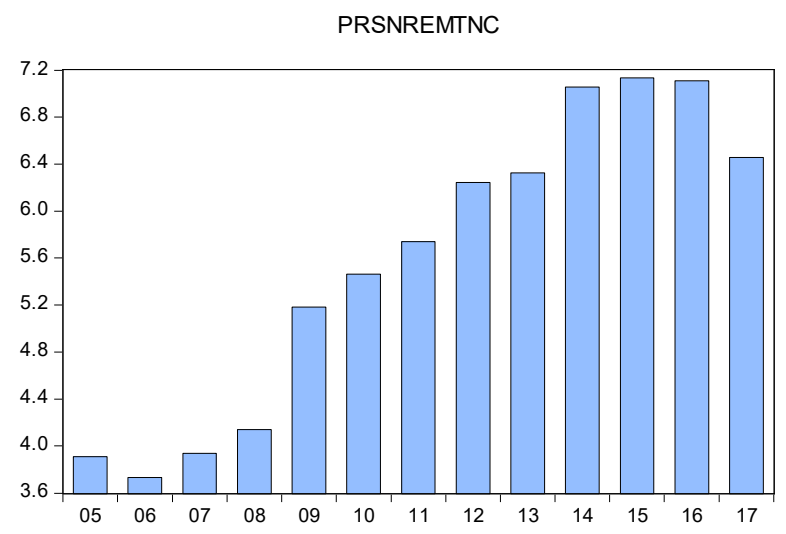

1.1.1.Remittances and Financial downturns of Economy:

Pakistan is facing a challenging situation. Since the formation of Pakistan, currency rate has been fluctuated but in last ten years it became more cheaply even dollar exchange rate touched at peak of the history due to unfavorable economic conditions. Gross Domestic Product, the unemployment rate, the inflation rate, the interest rate and the exchange rate give a summary of the macroeconomic stability of an economy. These economic indicators are influenced or can be controlled by generated different income resources for an economy and Personal remittances is one of them. Personal remittances, earnings of Pakistani citizens working in abroad has been increased during last decades. It is a source of deterring negative aspects of unemployment without any investment or increasing debts.

Poverty as another economic indicators has an influence and is influenced by prejudicing of migration permanently or temporary. In Pakistan increasing in the price of basic goods and education leads to increase in searching of sources of income aside.In Pakistan, poverty rate has been improved due to awareness in the people to explore resources of generating earnings and to attain basic goals of a standard living as well.In the following graph poverty head count ratio at national level is gradually declining.

\section{PTY}

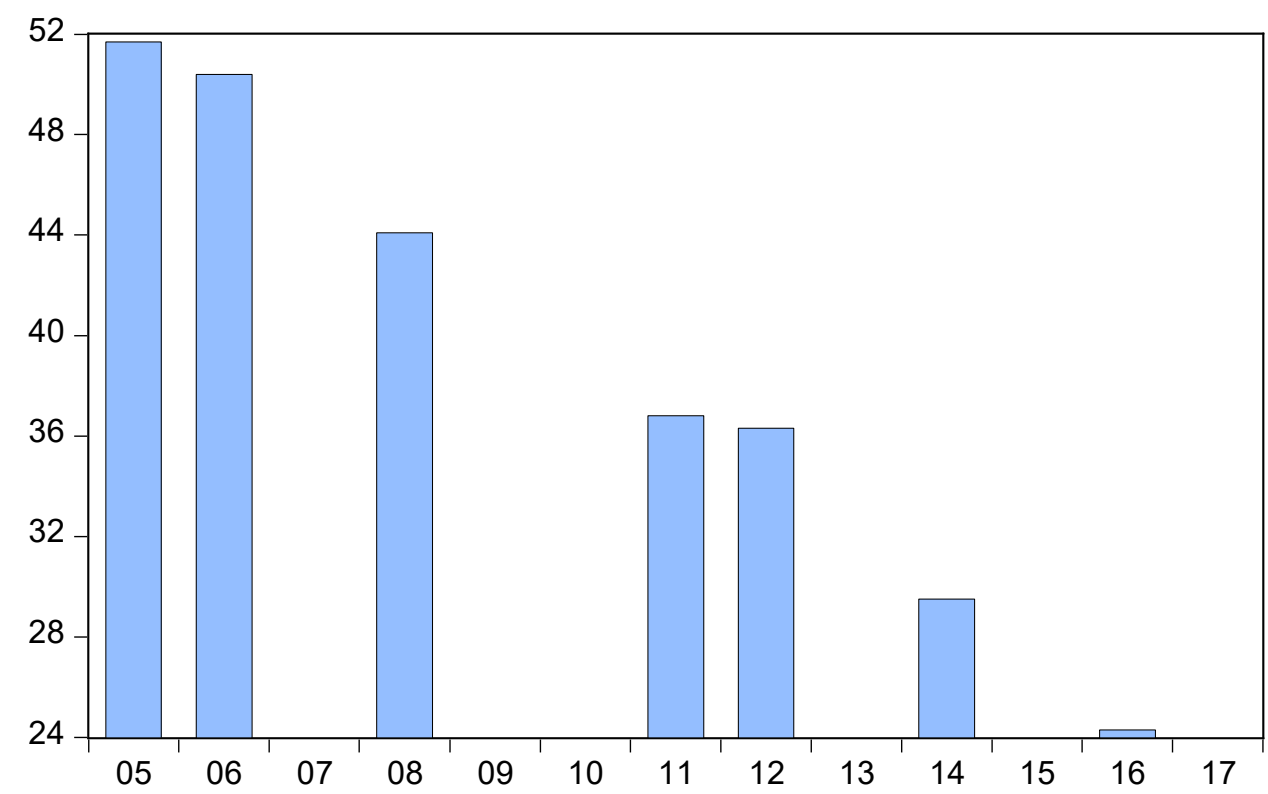

Balance of trade is an essential essence to elaborate financial health of an economy. In economics and finance, current account balance is the difference of savings and investments. Beside this world bank added a new item" personal remittances "a part of currency transfers. Increase in remittances will save economy from drastic imbalances.

High inflows of foreign currency is unfavorable for currency valuation. Increase in high remittances receipts leads to high inflow of foreign currency one hand and devaluation of local currency other hand. Due to currency depreciation, exports become cheaper and demand or value of local products in foreign market become less competitive. 
1.2. Scope of Study:

The scope of study will be very beneficial:

- To identify sources of investments for individuals to regenerate monetary benefits by remittances.

- For Ministry of Finance to identify the sources of finance without affecting economic health of Pakistan.

- To check and balance those factors which stabilize currency valuation along with remittances.

1.3. Purpose of Study:

This study is conduct to determine the following:

$>$ Interaction between personal remittances and currency valuation

$>$ To identify significant correlation between economic indicators and personal remittances

$>$ To check contribution of personal remittances in generating current account receipts.

\section{Literature Review:}

Every phenomenon has advantages and disadvantages, remittances have its good and bad effects on economy such as decrease in labor, culture of dependency on the host country and appreciation of exchange rate(Catalina Amuedo).Detmar Meyer and Adela Shera conducted a study to explore the contribution of remittances in economic growth of seven different countries during the sample year 199-2013 by applying regression analysis and heteroskedasticity test. Model consist of GDP growth rate, House consumption, real exchange rate, total debt etc. and found overall significance impact of remittances on the whole growth model. In addition, Kristina Mustuzeviciute and Mindaugus Butkus checked impact of remittances on long run economic growth over the period of 1990-2014 by using OLS approach and found positive impact of remittances on economic growth. Mr. Udo Kock and Yan Sun published in IMF working paper regarding home remittance in Pakistan and stated that remittance is contributing In GDP and internal growth of Pakistan. In addition, Mr.Muneer Khan ( 2007)quoted regarding home remittance that home remittance is a function of import and there is positive relationship between income and imports.

Workers remittances which is known as personal remittances and consider an important item of balance of payment It is the largest source of inflows without any risk and mobility of resouces.It helps to reduce current account deficits in terms of foreign currency at very low cost. Mohammad Abdul Hannan Pradhan and sabihal Afrin(2012) investigated contribution of remittances to stabilize current account balance of Bangladesh economy in the era of 1998-2010.Vector Error Correction(VEC)model was adopted to show the linearity of remittances and current account balances and found significant relation between current account balance and remittances.

In developing countries, there is always a need of inflows driven policies to repel the negative impact of high outflows in the shape of increase in imports. Remittances is one of the source of supplying foreign exchange in the money market.Afolabi o Adejuno and Professor Sylvanus (2017) conducted a study to investigate reality of exchange rate phenomenon created by increase in inflows in Nigeria.OLS technique was used to check level of significance of variables on different sectors of economy and concluded that remittances indirectly induced loss of merchandise export competitiveness due to appreciation of currency. To support this, Ripon Roy and Md Moklesur Rahman (2014) piloted a study on relationship between remittances and inflation in Bangladesh along with floating exchange rate scenario.ADF unit root test applied on econometric model nd found significant relation between food inflation and remittances.

South Asian countries are dominant for cheap labor market for European countries. Pakistan is one of the top countries which has high trend of immigration along with cheap rate of labor forces. To elaborate this, Muhammad Asad, Shujaat Haider and Saadia Yousuf conducted a study on Pakistan's macroeconomic indicators during 19752010.Co-integration technique and SML model has been constructed on annual time series data and found unidirectional correlation between unemployment and remittances while Ermira Hoxha Kalaj identified the negative impact of remittances on labor market of Albania.

Unemployment is the major cause behind emigration of labor force towards developed countries. Increase in labor supply leads to increase in remittances. To identify push factors of remittances, Dayangku Aslinah, Roslinah Mahmud and Rostika Petrus (2017) conducted a study on Indonesian immigrants to Malaysia in the time span of 1982-2011 and concluded that unemployment rate is significantly related with Indonesia immigration to Malaysia and increase in remittances in Indonesia as well.

\section{Methodology:}

3.1. Data Collection Technique:

As there are two methods of collecting data Primary and Secondary, but this study is totally based on Secondary data. 


\subsection{Sources of Secondary Data:}

- Pakistan Statistics Bureau

- Economic surveys of Pakistan

- State bank of Pakistan's annual records of trade and payments

- Annual reports of State Bank of Pakistan

- Ministry of Pakistan

\subsection{Sample Size:}

Time period from 2005-2017 is taken as a sample period because in this there is a radical change in economic stability furthermore there is also an increment in current account deficits which adversely affected reputation of trade and exchange rates of Pakistan .

3.4. Modeling Frame work:

Econometric Model:

$Y=\beta_{0}+\beta_{1}\left(\chi_{1}\right)+\beta_{2}\left(\chi_{2}\right)+$ $+\mu$

Model Driven:

Personal Remittances $=\beta_{0}+\beta_{1}$ Capital account balance $+\beta_{2}$ Exchange rate of US dollar $+\beta_{3}$ Inflation $+\beta_{4}$ unemployment $+\mu$

EXPECTED SIGNS:

- $\beta_{0}=$ ?

- $\beta_{1}<0$

- $\quad \beta_{2}>0$

- $\beta_{3}>0$

- $\beta_{4}>0$

\subsection{HYPOTHESIS:}

$\mathrm{Hi}_{1}$ : Personal Remittance is significant and correlated with capital account balances.

$\mathrm{H}_{01}$ : Personal Remittance is insignificant and correlated with capital account balances.

$\mathrm{Hi}_{2}$ : Personal Remittance is significant and correlated with exchange rate.

$\mathrm{H}_{02}$ : Personal Remittance is insignificant and correlated with exchange rate.

$\mathrm{Hi}_{3}$ : Personal Remittance is significant and correlated with inflation.

$\mathrm{H}_{03}$ : Personal Remittance is insignificant and correlated with inflation.

Hi4: Personal Remittance is significant and correlated with unemployment.

$\mathrm{H}_{04}$ : Personal Remittance is insignificant and correlated with unemployment.

\subsection{Data Handling:}

Data is handled through EVIEWS software by analyzing statistical tests:

Statistical Tests:

$>$ level of significance $=95 \%$

$>$ Probability $\leq 0.05$

$>$ Correlation

\section{Results Estimation:}

4.1. DESCRIPTIVE STATISTICS TABLE:

\begin{tabular}{|l|c|c|c|c|c|}
\hline & CAB & EXRT & INF & PRSNREMTNC & UNEMPL \\
\hline Mean & -3.094971 & 83.78812 & 9.173739 & 5.571403 & 3.185462 \\
\hline Median & -2.374882 & 85.50170 & 7.921084 & 5.741443 & 3.039000 \\
\hline Maximum & -0.763217 & 104.6971 & 20.28612 & 7.135673 & 6.528000 \\
\hline Minimum & -9.204316 & 59.35760 & 2.529328 & 3.730765 & 0.650000 \\
\hline Std. Dev. & 2.475924 & 18.05164 & 4.855685 & 1.287470 & 1.709813 \\
\hline Skewness & -1.205659 & -0.267016 & 0.747470 & -0.245467 & 0.258054 \\
\hline Kurtosis & 3.715107 & 1.527838 & 3.199401 & 1.580135 & 2.394718 \\
\hline Jarque-Bera & 3.426492 & 1.328411 & 1.232080 & 1.222560 & 0.342730 \\
\hline Probability & 0.180280 & 0.514682 & 0.540079 & 0.542656 & 0.842514 \\
\hline Sum & -40.23463 & 1089.246 & 119.2586 & 72.42823 & 41.41100 \\
\hline Sum Sq. Dev. & 73.56242 & 3910.338 & 282.9322 & 19.89093 & 35.08153 \\
\hline Observations & 13 & 13 & 13 & 13 & 13 \\
\hline
\end{tabular}

The above table shows the mean, median, standard deviation of each variable, the highest the mean and 
standard deviation show highest deviation in data.

4.2. Correlation Matrix:

\begin{tabular}{|c|c|c|c|c|c|}
\hline & CAB & EXRT & INF & PRSNREMTNC & UNEMPL \\
\hline CAB & 1.000000 & 0.546708 & -0.360420 & 0.600773 & -0.555929 \\
\hline EXRT & 0.546708 & 1.000000 & -0.545094 & 0.983845 & -0.627254 \\
\hline INF & -0.360420 & -0.545094 & 1.000000 & -0.527515 & -0.018161 \\
\hline PRSNREMTNC & $\mathbf{0 . 6 0 0 7 7 3}$ & $\mathbf{0 . 9 8 3 8 4 5}$ & $\mathbf{- 0 . 5 2 7 5 1 5}$ & $\mathbf{1 . 0 0 0 0 0 0}$ & $\mathbf{- 0 . 6 4 2 5 2 8}$ \\
\hline UNEMPL & -0.555929 & -0.627254 & -0.018161 & -0.642528 & 1.000000 \\
\hline
\end{tabular}

The data has analyzed through Eviews software by using correlation and regression. The correlation test indicates the relationship between the variables. According to above table there is a positive or negative correlation exist between dependent and independent variables. Exchange rate is positively strong correlated with personal remittances, unemployment and inflation have moderate and negative correlation with personal remittances while current account balance is moderately and positively correlated.

4.3. Inferences:

\begin{tabular}{|l|l|l|}
\hline Independent Variable & Dependent Variable & Comments \\
\hline $\begin{array}{l}\text { CAPITAL ACCOUNT } \\
\text { BALANCE }\end{array}$ & PERSONAL REMITTANCE & $\begin{array}{l}\text { POSITIVELY AND MODERATELY } \\
\text { CORRELATED WITH EACH OTHER }\end{array}$ \\
\hline EXCHANGE RATE & PERSONAL REMITTANCE & $\begin{array}{l}\text { STRONG POSITIVE } \\
\text { CORRELATION IS EXISTED. }\end{array}$ \\
\hline INFLATION & PERSONAL REMITTANCE & $\begin{array}{l}\text { NEGATIVE AND MODERATE } \\
\text { CORRELATION IS EXISTED }\end{array}$ \\
\hline UNEMPLOYMENT & PERSONAL REMITTANCE & $\begin{array}{l}\text { NEGATIVE AND MODERATE } \\
\text { CORRELATION IS EXISTED }\end{array}$ \\
\hline
\end{tabular}

\subsection{ESTIMATED EQUATION:}

Dependent Variable: PRSNREMTNC

Method: Least Squares

Date: 02/07/19 Time: 00:23

Sample: 20052017

Included observations: 13

\begin{tabular}{|c|c|c|c|c|}
\hline Variable & Coefficient & Std. Error & t-Statistic & Prob. \\
\hline $\mathrm{C}$ & -0.012718 & 0.954599 & -0.013323 & 0.9897 \\
\hline $\mathrm{CAB}$ & 0.048429 & 0.039929 & 1.212867 & 0.2598 \\
\hline EXRT & 0.067636 & 0.007480 & 9.042236 & 0.0000 \\
\hline INFT & 0.006114 & 0.023039 & 0.265396 & 0.7974 \\
\hline UNEMPL & 0.003395 & 0.074224 & 0.045738 & 0.9646 \\
\hline R-squared & 0.973896 & Mean dependent var & & 5.571403 \\
\hline Adjusted R-squared & 0.960845 & S.D. dependent var & & 1.287470 \\
\hline S.E. of regression & 0.254761 & Akaike info criterion & & 0.386738 \\
\hline Sum squared resid & 0.519224 & Schwarz criterion & & 0.604026 \\
\hline Log likelihood & 2.486203 & Hannan-Quinn criter. & & 0.342075 \\
\hline F-statistic & 74.61798 & Durbin-Watson stat & & 1.755996 \\
\hline Prob(F-statistic) & 0.000002 & & & \\
\hline
\end{tabular}

In the above equation: R Square show Coefficient of Determination defines the square of Coefficient of Correlation. The R Square value (0.973) means 97.3\% reliable to be used for estimation of population. The Std. Error is important because they reflect how much sampling Fluctuation a statistic will show. The R change shows the differences between R-value \& Adjusted R square.

Durbin Watson test value lies in significant region which indicates that there is no autocorrelation in the samples.The $\mathrm{F}$ change shows the combination of all variable and overall significances of the Model. 


\subsection{Actual, Fitted, Residual Graph:}

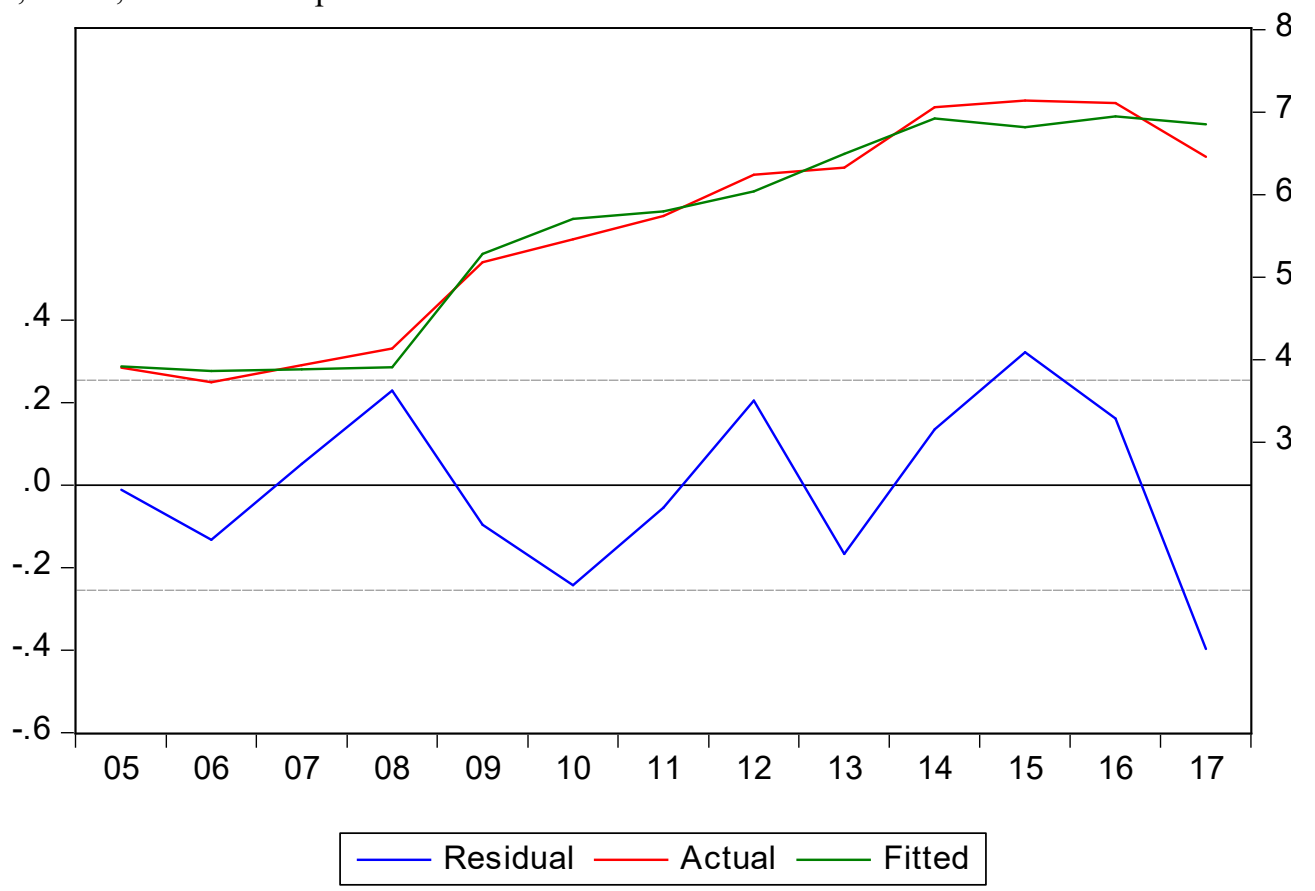

The above graph shows the tracing of model, the tracing of the model indicates minor error in a model as adjusted R-Squared indicated as well.

4.6. Results Analysis:

Dependent Variable: PERSONAL REMITTANCE

\begin{tabular}{|c|c|c|c|c|c|}
\hline Ind.Variable & Coefficient & t-value & Prob. & Corrl. & $\begin{array}{l}\text { Hypothesis } \\
\text { Accepted/Rejected }\end{array}$ \\
\hline $\mathrm{CAB}$ & 0.048429 & 1.212867 & 0.2598 & 0.600773 & $\begin{array}{l}\mathrm{Hi}_{1}: \text { Rejected } \\
\mathrm{H}_{01}: \text { Accepted }\end{array}$ \\
\hline XRATE & 0.067636 & 9.042236 & 0.0000 & 0.983845 & $\begin{array}{l}\mathrm{Hi}_{2}: \text { Accepted } \\
\mathrm{H}_{02}: \text { Rejected }\end{array}$ \\
\hline INFT & 0.006114 & 0.265396 & 0.7974 & -0.527515 & $\begin{array}{l}\mathrm{Hi}_{3}: \text { Rejected } \\
\mathrm{H}_{03}: \text { Accepted }\end{array}$ \\
\hline UNEMPL & -142.0205 & 0.003395 & 0.9646 & -0.642528 & $\begin{array}{l}\mathrm{Hi}_{4}: \text { Rejected } \\
\mathrm{H}_{04}: \text { Accepted }\end{array}$ \\
\hline
\end{tabular}

\subsection{Conclusion}

Personal remittance is one of an essential factor to eradicate economic instabilities and now has become an item included in balance of payment located at the portion of current account balance. The study is aimed to investigate the impact and interaction between personal remittances and macroeconomic indicators. Personal remittance is counted as a catalyst for increment in foreign inflows which has different pros and cons such as devaluation of currency. According to all above analysis it is explored that exchange rate is highly significant and positively correlated with personal remittances while current account balance, unemployment and inflation are labelled as insignificant by above analysis for this study.

\subsection{Recommendations}

To increase remittance for productive uses following suggestions are extracted for relevant authority of policy makers:

1) To reduce transaction cost of sending remittances so that people found easier to send huge amounts of money.

2) Government of Pakistan should manipulate policies for the productive use of remittances inflows to flourish SME's sector of Pakistan.

\section{References}

1) Dietmar Meyer and Adela Shera (2017)," The impact of remittances on economic growth: An econometric model" ScienceDirect EconomiA 18 (2017) 147-155.

2)Definition of Personal Remittances in the Balance of Payments Context, Eighteenth Meeting of the IMF 
Committee on Balance of Payments Statistics Washington, D.C., June 27-July 1, 2005.

3) Mohammad Abdul Hannan Pradhan, Sabiha Afrin, Mohammad Rafiqul Islam (2012)," Contribution of Remittance on Current Account of Balance of Payments in Bangladesh: VECM Estimation".

4) Mohammad Nishat and Nighat Bilgrami,"The Determinants of Worker's Remittances in Pakistan "The Pakistan Development Review 32:4 part ii (winter 1993) pp 1235-1245.

5) Afolabi O. Adejumo and Professor Sylvanus I. Ikhide(2017)," Remittance Inflows, Real Exchange Rate Movements and Sectoral Performance in Nigeria" European Journal of Economics and Business Studies.

6) Dayangku Aslinah Abd. Rahim,Roslinah Mahmud and Rostika Petrus Boroh," RELATIONSHIP OF UNEMPLOYMENT RATE AND REMITTANCE WITH INDONESIAN IMMIGRATION IN MALAYSIA”,PROCEEDINGS ICE 2017 P445 - P453 ISBN 978-967-0521-99-2.

7) Kristina Matuzeviciute and Mindaugas Butkus(2016)," Remittances, Development Level, and Long-Run Economic Growth" MDPI.

8) Catalina Amuedo,"The good and Bad in Remittance flows"IZA World of Labour.

9) Muhammad Asad, Shujahat Haider Hashmi, Saadia Yousaf (2016)," Nexus between workers' remittances,unemployment, labor migration and economic growth in Pakistan" International Journal of Organizational Leadership 5(2016) 360-379.

10) Stephen Drinkwater, Paul Levine and Emanuela Lotti(2003)," The Labour Market Effects of Remittances".

11)Ermira Hoxha Kalaj(2009)," Do Remittances Alter Labor Market Participation? A Study of Albania" MPRA Paper No. 48271.

12) Ripon Roy and Md. Mokhlesur Rahman (2014)," An empirical analysis of remittance-Inflation relationship in Bangladesh: post-floating exchange rate scenario" MPRA Paper No. 55190.

13) Charaf-Eddine Moussir and Safaa Tabit(2016)," Macroeconomic Determinants of Migrants' Remittances: Evidence from a Panel of Developing Countries" MPRA Paper No. 72956.

14) Udo Kock and Yan Sun (2011)," Remittances in Pakistan - why have they gone up, and why aren't they coming down?'IMF Working Paper WP/11/200.

15) Sadaf Alam, S. M Shoaib Wasim and Bashir Ahmad," Macroeconomic Determinants of Workers' Remittances: Pakistan, a Case in Point".

16) Mr.Muhammad Azam and Sana Siddiqui publications in International Journal of Economics and Financial Issues Vol. 2, No. 1, 2012, pp.33-40. 